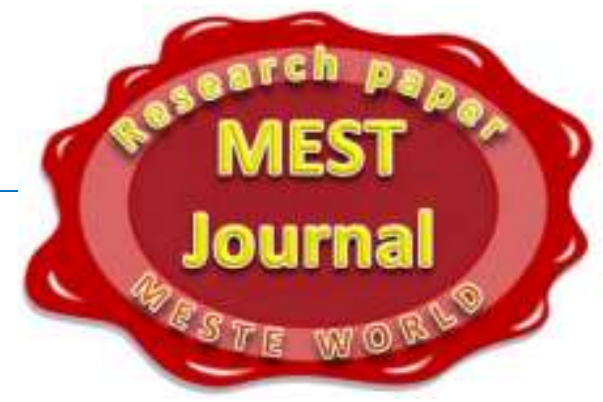

\title{
WAS MILTON FRIEDMAN A SOCIALIST? YES.
}

\section{Walter E. Block}

Harold E. Wirth Eminent Scholar Chair in Economics and Professor of Economics, College of Business Administration, Loyola University New Orleans, 6363 St. Charles Avenue, Box 15, Miller 321, New Orleans, LA 70118

\section{(C) MESTE NGO}

JEL category: B, B59

\section{Summary:}

Milton Friedman was a socialist, because his publications and speeches meet the criterion for the definition of this word: government ownership or control over significant sectors of the economy particularly means of production, such as money, roads; and/or redistributionist schemes such as his negative income tax. This is a controversial claim. It is backed up by the evidence.

\section{Keywords:}

Milton Friedman, socialist, means of production, income redistribution

\section{Introduction}

Before we can answer any such question, we must be clear on what socialism is. Then and only then can we ascertain whether, if, and to what extent was Friedman a socialist. But, before we do that, ${ }^{1}$ let us reflect upon why it is important to even ask this question, let alone answer it in a careful systematic way. There are several reasons.

First, categorization is an important tool of scholarly scientific pursuit. It is an exaggeration to claim that biology (genus, species, family) and

The address of the author:

Walter Block

毒” wblock@loyno.edu

\footnotetext{
${ }^{1}$ Since many people will object to this question even being posed
}

chemistry (the periodic table) consists of nothing but compartmentalization; however, there is surely a germ of truth in so outlandish a claim. In like manner, law distinguishes between legal and illegal, ${ }^{2}$ philosophy is commonly divided into subjects such as ethics, metaphysics, epistemology, and also into schools of thought such as utilitarianism, deontology, ordinary language (analytic), hermeneutics, existentialism, etc.; sociology partakes of both structuralism and functionalism; in economics there are the Marxist, Austrian and mainstream

\footnotetext{
${ }^{2}$ Antitrust law, supported by Friedman (1999), is an exception to this rule. In that case, a businessman can be found guilty of charging too high a price (profiteering, price gouging), too low a price (predatory price cutting, price warfare) or even the same price as everyone else (cartelization, conspiracy).
} 
or neoclassical schools of thought; in psychology there are Jungians, Rogerians, Freudians, behavioralists, etc. With all this plethora, is the distinction between socialists and capitalists, alone, to be ignored? Hardly.

A second reason for the present inquiry is that Milton Friedman is known far and wide as a supporter of capitalism, free enterprise, private property rights, etc. Summers (2006) said Friedman's great popular contribution was "in convincing people of the importance of allowing free markets to operate." Here is a similar quote: "(Milton Friedman) advocated minimizing the role of government in a free market as a means of creating political and social freedom" (Donahue, 2007). Here is another: "Milton Friedman was the twentieth century's most prominent advocate of free markets" (Anon, The concise encyclopedia of economics - Milton Friedman (1912 - 2006), 2008). Here is what he said about himself (Friedman M. , 1999) in this regard: "... a believer in the pursuit of self-interest in a competitive capitalist system." According to Doherty (2012), Friedman self-describes as a person "who...preach[es] laissez faire." Can it be that such a description is justified? Or is it the case that the very opposite is far nearer to the truth? The very title of the present essay exhibits the viewpoint on this matter of the present author.

Third, enquiring minds want to know the truth about this issue because in all too many cases, critics of the free enterprise system are likely to say that even Milton Friedman supports some governmental program or other. You, therefore, in not agreeing with this scholar, place yourself outside the realm of responsible discourse. If Friedman, however, is the socialist I claim he is, then this rejoinder is no longer open to the explicit enemies of economic freedom; all such accusations against true libertarians would be at one fell swoop defanged. This, alone, would render the present inquiry justified.

In section 2 of this paper we base our analysis on the assumption that socialism is defined in terms of governmental ownership of the means of production." Section 3 is given over to assessing Friedman's role in terms of the "from each... to each" definition of socialism. The role of section 4 is to deal with objections to our thesis. We conclude in section 5 .

\section{Socialism: state ownership of capital goods}

So we now return to our initial question: what is socialism $?^{3}$ The most technical and perhaps the most accurate definition of this concept is, Government ownership of all of the means of production, e.g., capital goods. States Mises (2009): "My own definition of Socialism, as a policy which aims at constructing a society in which the means of production are socialized, is in agreement with all that scientists have written on the subject." The U.S.S.R., North Korea, Cuba, China, many countries in Eastern Europe and Asia before, during and after World War II would qualify under this definition. Clearly, Friedman cannot be a socialist in this sense, since large parts of his career were spent inveighing against precisely these types of institutional arrangements.

But, there are socialists, and then there are socialists. Suppose a nation's government owns not $100 \%$ of all capital goods, but $90 \%, 80 \%$, $70 \%$, etc. It what point does such a country cease being socialist, and begin its move toward a mixed economy? The point is that there is a continuum (Block \& Barnett II, Continuums, 2008.) in this measurement, as there is in many others. ${ }^{4}$ States Hoppe (Hoppe, The Economics and Ethics of Private Property: Studies in Political Economy and Philosophy. Second Edition., 2006) in this regard: "Socialism must be conceptualized as an institutional interference with or aggression against private property and private property claims...(Capitalism) on the other hand, is a social system based on the explicit recognition of private property and of nonaggressive, contractual exchanges between

\footnotetext{
${ }^{3}$ Socialism may be broken down into its voluntary and coercive strands. In the former case, there are the nunnery, convent, kibbutz, commune, collective, syndicalist, cooperatives, monastery, abbey, priory, friary, religious community; in the latter, the economies of socialist countries such as Cuba, North Korea, the USSR, Nazi Germany, etc. We will use the word "socialism" in the latter understanding throughout this paper.

${ }^{4}$ Is a person tall? Short? It all depends.
} 
private property owners." In like manner, whether a scholar such as Friedman is a socialist or not, depends upon where on this spectrum he lies, in terms of what percentage of capital goods he wants the government to own.

However, outright explicit ownership is only a first approximation. Ludwig Wittgenstein was walking down the street with Norman Malcolm. The first philosopher said to the second, I'll give you these trees, provided you do nothing to them, nor prevent the previous owner from doing anything he pleases with them. ${ }^{5}$ The point is, there is ownership, and then there is ownership. Or, to put this in other words, control is what ownership is all about. The Nazi socialist government was not extreme in its explicit ownership of the means of production. But that version of socialism, that is, fascism, was earmarked by implicit state ownership, or control, of capital goods. The pertinent question then becomes, To what extent did Friedman advocate government ownership or control of the means of production.

Let us list the ways.

First and foremost, this economist supported the Federal Reserve System all throughout his professional life. ${ }^{6}$ That organization of course

\footnotetext{
${ }^{5}$ Here is the exact quote (Malcolm, 2001, p. 29): "On one walk he 'gave' to me each tree that we passed, with the reservation that I was not to cut it down or do anything to it, or prevent the previous owners from doing anything to it: with these reservations it was henceforth mine." I owe this cite to David Gordon.

${ }^{6}$ It cannot be denied that he was disappointed with the fact that the Fed did not follow anything like his famous 3\% rule, but he did not join Ron Paul (2010) in calling for the entire elimination of this organization, root and branch. Doherty (2012) gives an alternative view: "Despite his earlier statement that government paper currency monopolies were necessary, as this book's 1984 essay 'Freezing HighPowered Money' shows, the later Friedman was as radical as Ron Paul in his opposition to the Fed. Friedman called for elimination of the Federal Reserve's role in 'determining the quantity of money' and says its regulatory and service role to the banking system 'could, if desired, be continued, preferably by combining it with the similar roles of the FDIC.' In other words, End the Fed!" It hardly
}

does not own the money stock, but it certainly controls it. ${ }^{7}$ Friedman was an inveterate hater of the gold standard, denigrating its advocates as "gold bugs." In the view of Rothbard (Rothbard, Milton Friedman Unraveled, 1971 [2002]): “... Milton Friedman is a radical advocate of cutting all current ties, however weak, with gold, and going onto a total and absolute fiat dollar standard, with all control vested in the Federal Reserve System." Whenever people were free to choose, ${ }^{8}$ they chose gold as their money, and sometimes silver. The "gold standard" is, then, properly characterized as free market money. Friedman is clearly on the socialist side of this very important means of production.

Friedman was a road socialist. He favored ${ }^{9}$ government ownership and control over the nation's highways and streets (Seagraves, 2008)

seems like an "end" to the Fed if its role is merely transferred to other organs of government. It cannot be denied that Friedman did explicitly support the "end the fed" movement. He stated: "Any system which gives so much power and so much discretion to a few men, [so] that mistakes -- excusable or not -- can have such far reaching effects, is a bad system. It is a bad system to believers in freedom just because it gives a few men such power without any effective check by the body politic -- this is the key political argument against an independent central bank. . .To paraphrase Clemenceau: money is much too serious a matter to be left to the Central Bankers." (Friedman M. , 2012A)

However, Friedman's ending of the fed is of a very different variety than that of a Ron Paul or a Murray Rothbard. The latter wanted not merely to "end the fed" but to call a halt to any government involvement in the monetary stock. Friedman wanted not so much to end the fed as to rein it in, limit it to following his $3 \%$ rule for monetary increase.

${ }^{7}$ For the view that money is a capital good, see Barnett and Block (2005A).

${ }^{8}$ This of course is the title of Friedman (1980), and also his television series (Friedman M. , 2012B). But, we can see that Friedman's advocacy of "freedom to choose" is a rather limited one.

${ }^{9}$ This claim is based on an informal debate I had with Milton Friedman at a Liberty Fund Conference, sometime in the 1980s. However, for an alternative perspective, see Friedman and Boorstin (1951). See also Lindsey (2006). 
These are clearly capital goods. ${ }^{10}$ As such, this opinion of his further qualifies him as a socialist. Nor did Friedman support the full and entire conversion of all public schools to private hands. Rather, he urged that the state maintain ownership of these facilities and control them through a voucher system. If that is not support for governmental ownership and/or control over the means of production, then nothing is.

Another socialist and disastrous ${ }^{11}$ policy of Friedman's (1962) was to support the concept of "neighborhood effects." This is the idea that since we all affect each other, this constitutes a market failure, and justifies government intervention into the economy. Rothbard (Rothbard, Milton Friedman Unraveled, 1971 [2002]) explains:

"Friedman maintains that it is legitimate for the government to interfere with the free market whenever anyone's actions have 'neighborhood effect.' Thus, if A does something which will benefit $B$, and $B$ does not have to pay for it, Chicagoites consider this a 'defect' in the free market, and it then becomes the task of government to 'correct' that defect by taxing $B$ to pay A for this 'benefit.'

"It is for this reason that Friedman endorses government supplying funds for mass education, for example; since the education of kids is supposed to benefit other people, then the government is allegedly justified in taxing these people to pay for these 'benefits.' (Once again, in this area, Friedman's pernicious influence has been in trying to make an inefficient State operation far more efficient; here he suggests replacing unworkable public schools by public voucher payments to parents - thus leaving intact the whole concept of tax-funds for mass education.)"

Prof. Friedman also favored eminent domain, the forceful takeover of private property by government, at prices, if any, set by the latter. This is hardly in keeping with the tenets of laissez faire capitalism, which is predicated on

\footnotetext{
${ }^{10}$ Rothbard (1997) to the contrary notwithstanding. In his view, anything owned by the government must necessarily be a consumer, not a capital good. For a critique, see Barnett and Block (2009A).

${ }^{11}$ I repeat myself here.
}

voluntary exchanges, not coercive ones. According to Northrup (2003, p. 494)

"Milton Friedman provided the theoretical basis for eminent domain ... he described the forced removal of particular urban neighborhoods and their populations as a necessary plan for the improvement of the entire city. According to Friedman, as local governments selected neighborhoods for purposes of redevelopment, a decrease in low income housing led to the displacement of poor populations. But the social consequences for slum residents translated into gains for the greater community as luxury apartments and commercial buildings replaced dilapidated buildings..."

Now, it is indeed true that Friedman is in "good company" on this matter, in that virtually all economists, politicians and city planners would agree with his assessment. But, that will not deflect in the slightest the charge that he is a socialist on this issue.

\section{Socialism: from each, to each}

There is another definition of socialism against which we will now measure the contribution of Friedman. It is not as technically correct as the one we have been utilizing in our examination, but, is also mentioned in the literature: "from each according to his ability, to each according to his needs" (Polya, 2007) (Pena, 2011) (Marx, 1875). This is certainly in keeping with Hoppe (2006): “... there must then exist varying types and degrees of socialism and capitalism, i.e., varying degrees to which private property rights are respected or ignored. Societies are not simply capitalist or socialist. Indeed, all existing societies are socialist to some extent." For, surely, forcing rich people to give their hardearned money to those poorer than themselves would be a prime instance of disrespecting or ignoring private property rights.

How does Friedman measure up to socialism in this regard? Very well, unfortunately. ${ }^{12}$ His negative income tax fits this bill to a "T." Certainly, it constitutes a coercive transfer of funds from those with great ability to those

\footnotetext{
${ }^{12}$ Fortunately, from the perspective of the thesis of the present paper.
} 
presumably in need. What, precisely, is the negative income tax? According to Allen (1993):

"The idea of a negative income tax (NIT) is commonly thought to have originated with economist Milton Friedman, who advocated it in his 1962 book, Capitalism and Freedom...

"In its purest form a NIT promised a revolution in American social policy. Gone would be the intrusive and costly welfare bureaucracy, the pernicious distinctions between 'worthy' and 'unworthy' recipients, the perverse disincentives for work effort and family formation. The needy would, like everyone else, simply file annual-or perhaps quarterly-income returns with the Internal Revenue Service. But unlike other filers who would make payments to the IRS, based on the amount by which their incomes exceeded the threshold for tax liability, NIT beneficiaries would receive payments ('negative taxes') from the IRS, based on how far their incomes fell below the tax threshold.

"The NIT would thus be a mirror image of the regular tax system. Instead of tax liabilities varying positively with income according to a tax rate schedule, benefits would vary inversely with income according to a negative tax rate (or benefit-reduction) schedule. If, for example, the threshold for positive tax liability for a family of four was, say, $\$ 10,000$, a family with only $\$ 8,000$ of annual income would, given a negative tax rate of 25 percent, receive a check from the Treasury worth $\$ 500$ (25 percent of the $\$ 2,000$ difference between its $\$ 8,000$ income and the $\$ 10,000$ threshold). A family with zero income would receive $\$ 2,500$."

One difficulty with this proposal is that it would reduce at least the perceived need for charity from the rich in behalf of the poor, and, presumably, actual donations. Another is that it would further incentivize people to declare themselves poverty stricken, and even to act so as to bring about this result. ${ }^{13} \mathrm{~A}$ further difficulty is that it would entrench "welfare rights" into the tax code, as those with less earnings than the

\footnotetext{
${ }^{13}$ Supply curves slope in an upward direction. The more that is paid for a good or service the more of it there will be ceteris paribus, and this applies to poverty as much as to anything else.
}

cutoff point would have a "right" to their "negative tax." ${ }^{14}$ It is perhaps for these sorts of reasons that Ludwig von Mises dramatically rejected this idea. He is famous for walking out of the first Mont Pelerin Society meeting in 1947 in a huff, stating: "You're all a bunch of socialists" in response to a discussion of the NIT, and other such coercive income redistribution schemes. ${ }^{15}$

\section{Objections}

\subsection{Changes over time.}

According to this objection, the leopard has changed its spots. Friedman may have been a socialist early in his career, but he "grew in office," and was much less so later on. There is some truth to this. ${ }^{16}$ A much younger Milton Friedman was active in propagating the withholding tax (Rothbard, 2002); an older one actually apologized for this socialistic initiative (Friedman \& Friedman, 1998).

Something similar seems to have occurred with antitrust. States Friedman (1999):

"My own views about the antitrust laws have changed greatly over time. When I started in this

14 Lind ( 2012 ); Mullat (2012); Rothbard (1971 [2002]). The title of the former, and its source, is especially telling, given the overall thesis of the present paper. Charles Murray, a "libertarian" of the Friedmanesque variety, makes the point that "not only would people receive money they need, others would [not] know you are receiving money" (RB, 2012). But from a truly libertarian perspective, this would count as an argument against the NIT, not in favor of it.

${ }^{15}$ See on this Kaza (1997), Memehunter ( 2012), Ebenstein (2012). According to Milton Friedman: "The story I remember best happened at the initial Mont Pelerin meeting when he (Ludwig von Mises) got up and said, "You're all a bunch of socialists." We were discussing the distribution of income, and whether you should have progressive income taxes. Some of the people there were expressing the view that there could be a justification for it" (Wiki, 2012).

${ }^{16}$ Mitt Romney has been considered a weathervane of politics, in that he has changed his mind on so many, many issues. See on this: (Romney, 2012); (Huntsman, 2011); (TiMT, 2012); (Saletan, 2012). In like manner, although certainly to a lesser extent, all of these changes have rendered Milton Friedman a weathervane of political economy. 
Block W. Was Milton Friedman a socialist? Yes.

MEST Journal Vol.1 No.1 pp. 11 - 26

business, as a believer in competition, I was a great supporter of antitrust laws; I thought enforcing them was one of the few desirable things that the government could do to promote more competition. But as I watched what actually happened, I saw that, instead of promoting competition, antitrust laws tended to do exactly the opposite, because they tended, like so many government activities, to be taken over by the people they were supposed to regulate and control. And so over time I have gradually come to the conclusion that antitrust laws do far more harm than good and that we would be better off if we didn't have them at all, if we could get rid of them."

But this is not a root and branch attack on antitrust, of the sort taken by true libertarians. ${ }^{17}$ The strong implication here is that if these laws could somehow be modified so that they would not "be taken over by the people they were supposed to regulate and control" then Friedman's rejection of them would disappear. ${ }^{18}$

There is one topic upon which it can clearly be denied that Friedman became less socialistic as he aged and presumably "learned his lesson": school vouchers. ${ }^{19}$ Until the very end of his life,

17 (Anderson, et al., 2001); (Armentano, 1999); (Barnett, Block, \& Saliba., 2005); (Barnett, Block, \& Saliba., 2007); (Barnett \& Block, 2005A) (Barnett \& Block, 2007); (Block W. , Austrian Monopoly Theory a Critique, 1977A) (Block W. , 1982) (Block W. , 1994); (Block \& Barnett., 2009); (Boudreaux \& DiLorenzo, 1992); (Costea, 2003); (DiLorenzo T. J., 1996); (DiLorenzo \& High., 1988); (High, 1984-1985); (McChesney, 1991); (Rothbard, 2004 [1962]); (Shugart II, 1987); (Smith, 1983); (Tucker, Controversy: Are Antitrust Laws Immoral?, 1998A) (Tucker, 1998B)

${ }^{18}$ Doherty (2012) has been taken in by this supposed change of heart on antitrust: "Friedman tells a similar story while eulogizing his best friend and University of Chicago colleague George Stigler, an economist who became more opposed to the very antitrust laws the 1951 Friedman lauded earlier in the book the more he learned about them."

${ }^{19}$ For a critique of school vouchers from a libertarian point of view, see North (1976) (2011); Rockwell (1998), (2000), (2002); Rome and Block (2006); Rothbard (1971 [2002]), (1994), (1995); Salisbury (2003); Vance (1996); Yates (2002A), (2002B); Young and Block ( 1999). and even after it based upon his inheritance decisions, this socialist was a warm supporter of school vouchers. ${ }^{20}$ In his will he left a goodly portion of his wealth to the Friedman Foundation for School Choice. ${ }^{21}$ Another is public (socialist) roads, highways and streets. In Friedman and Boorstin (1951) there are some indications of a free enterprise perspective. Not so in the later period (Seagraves, 2008).

\subsection{Embarrassment}

Anyone who says Friedman was a socialist will bring embarrassment down upon the heads of all proponents of the free economy and the freedom philosophy. There is some truth in this claim, too. After all, this man is widely known if not as the most radical exponent of capitalism ever, at least among its all-time leaders. Anyone who deprecates this claim will be disrespected. Anyone who goes further and even asks if he is a socialist will be dismissed out of hand. And, a low rung in intellectual hell will be reserved for such as the present author who gives a positive answer to this question.

As against this, I am not seeking popularity. Rather, truth. And the evidence I have compiled above requires one and only one response: Friedman was indeed a socialist. Perhaps a moderate one. But a socialist nonetheless.

\subsection{Context}

Suppose we were to rank all people in the U.S. according to their political economic philosophies in the direction of a free society. We would award a score of 100 to anarcho-capitalists such as Murray Rothbard, Hans Hoppe, Lysander Spooner, Lew Rockwell. We would place in the 99th percentile limited government libertarians such as Ron Paul, Ayn Rand and Andrew Napolitano. We would earmark with a zero all those outright socialists, communists, fascists who favor income redistribution, complete government ownership and/or control over the means of production, such as Htiler, Stalin, Mao,

\footnotetext{
${ }^{20}$ (Gillespie, 2005)

${ }^{21}$ Its motto is "Advancing Milton \& Rose Friedman's vision of school choice for all children." See on (FF). Also see (Friedman M. , 2003)
} 
Pol Pot. More moderate socialists such as Barack Obama, Bernie Sanders, Bill and Hillary Clinton, Mayor Mike Bloomberg would earn a 5 on our scale, and Republicans of the ilk of Mitt Romney, Newt Gingrich, Rick Santorum, Buddy Roemer, Rick Perry, Michele Bachmann, Herman Cain, Rudy Giuliani, Fred Thompson and Tim Pawlenty a $7 .^{22}$ Where oh where would Milton Friedman rank in such an undertaking? It is difficult to ignore the conclusion that he would score somewhere in the 90s. Let us award him a 96, arguendo. This means he is more capitalist, and thus less socialist that people falling into the $95^{\text {th }}$ percentile or lower. ${ }^{23}$

From this two conclusions might be drawn. One, it is silly, it is absurd, it is diabolical, it is the ravings of a madman, to consider such a man a socialist. If Milton Friedman falls into the $96^{\text {th }}$ percentile of our socialist-capitalist spectrum in the direction of the latter, then, he cannot be characterized as the former. But there is an entirely different way to interpret these statistical assumptions: the entire world is socialist to one degree or another, Milton Friedman along with the rest of his socialist brethren. Just because the entire world has gone crazy, Friedman less so than many others, does not mean that he, too, has not been sucked in to that category.

The first interpretation is a relativistic one: since most people support socialism to a far greater degree than Friedman, he himself is not, cannot be, linked with them; he is not a socialist. Since very, very few people support capitalism to a

22 In my view, the Republican candidates are somewhat better than the Democrats on economic policy, slightly worse on personal liberties and foreign affairs.

${ }^{23}$ Another way of asking this question is, Under whose economic control would I rather live? Milton Friedman's or, pick your favorite GOP candidate from the 2012 election, mentioned above. The obvious answer is this Nobel Prize winning University of Chicago economist. I could count on him to unilaterally declare full free trade with all nations, rid us of occupational licensure, rent control, minimum wages, and hundreds of other such regulations. None of these others would even come close. greater degree than him, he must be counted as a member of that category.

The second interpretation is objective. I claim it is more scientific. It sets up criteria for socialism in terms of government ownership or control of basic resources, and redistributionist income schemes. It notes that Friedman fails this objective test in terms of roads, money, school vouchers, negative income taxes, etc. Therefore he is a socialist.

Let us try to make this case by analogy. Right now, there are objective criteria for an observation being considered a kangaroo. At present, there are relatively few such entities. But suppose a gigantic change took place. Most observations now fit into this category. Say, 96\% of all things became kangaroos. According to objective criterion, we would then say $96 \%$ of things are kangaroos, $4 \%$ of things are not. Period. According to relativist considerations, we would be tempted to say that big, or small, or dark, or light, or otherwise distinguished kangaroos were not really kangaroos. After all, a system that categorizes almost everything as a kangaroo cannot be a helpful one. The purpose of enterprises of this sort is to make distinctions. Therefore, we cannot allow virtually everything to be a kangaroo.

I suggest this is a good analogy. Yes, Friedman is less socialistic than $96 \%$ of people, we presume. According to the relativist viewpoint, he cannot be a socialist. But, according to objective scientific considerations, he most certainly is. From the point of view of making distinctions, it is absolute madness to count Friedman as a socialist. The word will lose virtually all, but not quite all, of its meaning, if we do so. However, from the perspective of maintaining an unwavering yardstick, it is imperative to view him in this way. How else can we measure how far to the left we have all moved in terms of economic policy prescriptions, well, most of us, if we do not? Mises, as usual, was correct. 
Block W. Was Milton Friedman a socialist? Yes.

MEST Journal Vol.1 No.1 pp. 11 - 26

Friedman is a socialist. ${ }^{24}$ For that matter, he and his entire Chicago School $^{25}$ are a "bunch of socialists."

Some might say in this regard it is not a good way to classify things if most items fall under only one category. It cannot be denied that the system employed in this paper places most people, Milton Friedman certainly included, on the socialist side of the ledger. However, the overwhelming majority of species are invertebrates. Some $95 \%$ of all animals lack a spinal chord. ${ }^{26}$ Does this render a distinction between invertebrates and vertebrates invalid? Of course not.

\subsection{Cognitive significance}

According to this objection, I emphasize that Friedman did not fully support the free market, and provide a good list of examples to support this. But what is gained by the extra step of calling Friedman a socialist? It adds nothing to the list of deviations and appears empty of cognitive significance.

But there is "cognitive significance." It is in this way, and only in this way, that we can demonstrate how far our society has come from

\footnotetext{
${ }^{24}$ States Rothbard (1971 [2002]): “... as we examine Milton Friedman's credentials to be the leader of free-market economics, we arrive at the chilling conclusion that it is difficult to consider him a freemarket economist at all."

${ }^{25}$ For criticisms of other members of the Chicago School on these grounds, see on Simons (Block W. E., 2002) (Rothbard, 2002); on Brozen and Posner (Block W. , 1994); on Becker (Murphy, 2008), on Becker and Coase (North, 1990); on Coase (Barnett \& Block., 2005B) (Barnett \& Block, 2007) (Barnett \& Block, 2009B); (Block W. , 1977B), (Block W. , 1995), (Block W. , 1996), (Block W. , 2000), (Block W. , 2003), (Block W. , 2006), (Block W. E., 2010A), (Block W. E., 2010B), (Block W. E., 2010C); (Block, Barnett, \& Callahan, 2005); (Cordato R. E., 1989), (Cordato R. E., 1992A), (Cordato R. E., 1992B), (Cordato R. E., 1997), (Cordato R. , 1998), (Cordato R. , 2000); (Fox, 2007); (Hoppe, 2004); (Krauss, 1999); (Krecke, 1996); (Lewin, 1982); (North, 1990) (North, 1992) (North, 2002); (Rothbard, 1982), (Rothbard, 1973); (Stringham E. , 2001); (Stringham \& White, 2004); (Terrell, 1999)

${ }^{26}$ (Encyclopedia, 2012)
}

its former embrace of laissez faire capitalism. This objection relies, for its coherence, on a relative measure. Yes, in this sense, it is barking mad to consider Friedman as a socialist, since there are so many, many people who are far more socialist than he. However, if and only if we use an absolute calculus can we see the movement of the entire society. Let us employ an analogy. According to the Flynn (1984), (1987), (2007), (2012) effect, all of our IQ measurements are rising over time. An individual with a high IQ many years ago might have been 4 standard deviations above the mean. If this Flynn effect long continues, a person with that IQ score will only be mediocre. According to the gist of this objection, it would be untoward to utilize an objective criterion; only a relative one would be significant. But this would hardly hold true if the Flynn effect is actually occurring.

\subsection{Mises, too, was a socialist}

If "socialist" includes those who favor any government ownership or control, then of course Mises would be a socialist as well Friedman. That may be technically true, according to the author's definition, but then by what criteria to we distinguish Mises from Marx, or Friedman from Marx?

This is a very powerful objection, in that I am very loath to consider Mises as a socialist. However, this objection, too, must be rejected. Mises may have had one or two deviations from true laissez faire capitalism, or anarcho capitalism; Friedman had more than a dozen. 'twas Mises who called Friedman a socialist, not the other way around. Perhaps the most powerful argument undermining this objection is that there is even a case to be made in behalf of the claim that Mises was actually an anarcho capitalist.

I take it as a given that secession, not merely to the state, county, city, borough, neighborhood level, but down to the individual, is a form of free market anarchism (Gordon, 1998); (Hülsmann, 2003); (Kinsella, 2009); (Kreptul, 2003); (McGee, Secession Reconsidered, 1994A), (McGee, 1994B). (See also (Secession Equals Anarhy, 2012); (Smithson, 2010) (Smithson, 2010); (Wright, 2010)) 
Block W. Was Milton Friedman a socialist? Yes.

MEST Journal Vol.1 No.1 pp. 11 - 26

Here are some statements from Mises that are compatible with this stance:

"A nation, therefore, has no right to say to a province: You belong to me, I want to take you. A province consists of its inhabitants. If anybody has a right to be heard in this case it is these inhabitants. Boundary disputes should be settled by plebiscite" (Mises L. v., 1969).

"No people and no part of a people shall be held against its will in a political association that it does not want" (Mises L. v., 1983).

'Liberalism (Mises' position - present author) knows no conquests, no annexations; just as it is indifferent towards the state itself, so the problem of the size of the state is unimportant to it. It forces no one against his will into the structure of the state.... When a part of the people of the state wants to drop out of the union, liberalism does not hinder it from doing so" (Mises, 1983, pp. 39-40, emphasis added).
"If it were in any way possible to grant this right of self-determination to every individual person, it would have to be done" (Mises L. , 1978, p. 109). For support of the claim that while Mises was not a free market anarchist, he came close, see (Kinsella, 2009)

As to distinguishing Friedman and Marx, the former was a moderate socialist, the latter a radical one.

\section{Conclusion}

Milton Friedman is a socialist. It matters not at all that most of the world is far more socialist than he. It would not deflect this accusation if he were the most capitalist, the least socialist, of any person on the entire planet. He would still be a socialist, objectively speaking. It matters not one whit that such a conclusion will prove to be an embarrassment among the cognoscenti, the intellectuals of political philosophy.

\section{Works Cited}

Allen, J. T. (1993). Negative Income Tax. The Concise Encyclopedia of Economics. Library of Economics and Liberty. Retrieved November 23, 2012, from http://www.econlib.org/library/Enc1/NegativelncomeTax.html

Anderson, W., Block, W., DiLorenzo, T. J., Mercer, I., Snyman, L., \& Westley., C. (2001). The Microsoft Corporation in Collision with Antitrust Law. The Journal of Social, Political and Economic Studies, 26(1, Winter), 287 - 302.

Anon. (2008). The concise encyclopedia of economics - Milton Friedman (1912 - 2006). Retrieved from Library of economics and liberty: http://www.econlib.org/library/Enc/bios/Friedman.html\#

Anon. (2012, 09 28). Secession Equals Anarhy. Retrieved from National Park Service: http://www.nps.gov/liho/historyculture/secanarchy.htm

Armentano, D. T. (1999). Antitrust: The Case for Repeal. Auburn, AL: Mises Institute.

Barnett, W. I., \& Block, W. (2007, 11). Coase and Van Zandt on Lighthouses. Public Finance Review, 35(6), 710-733.

Barnett, W. I., \& Block, W. E. (2005A). Money: Capital Good, Consumers' Good, or (Media of) Exchange Good? Review of Austrian Economics. 18 (2): , 179-194.

Barnett, W. I., \& Block, W. E. (2005A). Money: Capital Good, Consumers' Good, or (Media of) Exchange Good? Review of Austrian Economics, 18(2), 179-194.

Barnett, W. I., \& Block, W. E. (2009A). Investment and Consumption: A critique of Rothbard's claim that there can be no such thing as governmental 'investment'. Journal of Public Finance and Public Choice, 27(2-3), 183-188.

Barnett, W. I., \& Block., W. (2005B). Professor Tullock on Austrian Business Cycle Theory. Advances in Austrian Economics, 8, 431-443. 
Block W. Was Milton Friedman a socialist? Yes.

MEST Journal Vol.1 No.1 pp. 11 - 26

Barnett, W. I., Block, W., \& Saliba., M. (2007, Summer). Predatory pricing. Corporate Ownership \& Control, 4(4), 401-406.

Barnett, W., \& Block, W. (2009B). Coase and Bertrand on Lighthouses. Public Choice, 140(1-2), 1-13. Retrieved from http://dx.doi.org/10.1007/s11127-008-9375-x

Barnett, W., Block, W., \& Saliba., M. (2005, Summer). Perfect Competition: A Case of 'Market-Failure. Corporate Ownership \& Control, 2(4), 70-75.

Block, W. ( 1996). O.J.'s Defense: A Reductio Ad Absurdum of the Economics of Ronald Coase and Richard Posner. European Journal of Law and Economics, 3, 265-286. Retrieved from http://www.walterblock.com/publications/block_oj's-defense.pdf

Block, W. (1977A). Austrian Monopoly Theory - a Critique. The Journal of Libertarian Studies, I(4), 271-279.

Block, W. (1977B, Spring). Coase and Demsetz on Private Property Rights. The Journal of Libertarian Studies: An Interdisciplinary Review, I(2), 111-115. Retrieved from http://www.mises.org/journals/jls/1_2/1_2_4.pdf

Block, W. (1982). Amending the Combines Investigation Act. Vancouver: The Fraser Institute.

Block, W. (1994). Total Repeal of Anti-trust Legislation: A Critique of Bork, Brozen and Posner. Review of Austrian Economics, 8(1), 35-70.

Block, W. (1995). Ethics, Efficiency, Coasean Property Rights and Psychic Income: A Reply to Demsetz. Review of Austrian Economics, 8(2), 61-125. Retrieved from http://www.mises.org/journals/rae/pdf/rae8_2_4.pdf

Block, W. (2000, Spring). Private Property Rights, Erroneous Interpretations, Morality and Economics: Reply to Demsetz. Quarterly Journal of Austrian Economics, 3(1), 63-78. Retrieved from http://www.mises.org/journals/qjae/pdf/qjae3_1_8.pdf

Block, W. (2003, Summer). Private property rights, economic freedom, and Professor Coase: A Critique of Friedman, McCloskey, Medema and Zorn. Harvard Journal of Law and Public Policy, 26(3), 923-951. Retrieved from http://findarticles.com/p/articles/mi_go2782/is_3_26/ai_n6640908/?tag=content

Block, W. (2006). Coase and Kelo: Ominous Parallels and Reply to Lott on Rothbard on Coase. Whittier Law Review, 27(4), 997-1022.

Block, W. E. ( 2010B, Winter). Rejoinder to Brooks on Coase and Demsetz. Quarterly Journal of Austrian Economics, 13(4), 56-73. Retrieved from http://mises.org/journals/qjae/pdf/qjae13_4_3.pdf

Block, W. E. (2002, Fall). Henry Simons Is Not A Supporter of Free Enterprise. Journal of Libertarian Studies, 16(4), 3-36. Retrieved from http://www.mises.org/journals/jls/16_4/16_4_2.pdf

Block, W. E. (2010A). A Response to Brooks' Support of Demsetz on the Coase Theorem. Dialogue, 2. Retrieved from http://www.uni-svishtov.bg/dialog/2010/2.10.WB.pdf

Block, W. E. (2010C, Fall). Rejoinder to Boettke on Coasean Economics and Communism. Romanian Economic and Business Review, 5(3), 9-90. Retrieved from http://www.rebe.rau.ro/REBE\%205\%203.pdf

Block, W., \& Barnett II, W. (2008., 06). Continuums. Journal Etica e Politica / Ethics \& Politics, 1, 151166. Retrieved from http://www2.units.it/ etica/ ; http://www2.units.it/ etica/2008_1/BLOCKBARNETT.pdf

Block, W., \& Barnett., W. (2009, June/December). Monopsony Theory. American Review of Political Economy, 7(1/2), 67-109. Retrieved from http://www.arpejournal.com/ARPEvolume7number12/Block-Barnett.pdf; http://www.arpejournal.com/

Block, W., Barnett, W. I., \& Callahan, G. (2005). The Paradox of Coase as a Defender of Free Markets. NYU Journal of Law \& Liberty, 1(3), 1075-1095. Retrieved from 
Block W. Was Milton Friedman a socialist? Yes.

MEST Journal Vol.1 No.1 pp. 11 - 26

http://tinyurl.com/2hbzd4;

http://www.nyujll.org/articles/Vol.\%201\%20No.\%203/Vol.\%201\%20No.\%203\%20-

\%20Barnett,\%20Block\%20and\%20Callahan.pdf; http://tinyurl.com/2hbzd4

Boudreaux, D. J., \& DiLorenzo, T. J. (1992). The Protectionist Roots of Antitrust. Review of Austrian Economics, 6(2), 81-96.

Cordato, R. (1998, Spring). Time Passage and the Economics of Coming to the Nuisance: Reassessing the Coasean Perspective. Campbell Law Review, 20(2), 273-292.

Cordato, R. $(2000,09)$. Chasing Phantoms in a Hollow Defense of Coase. The Review of Austrian Economics, 13(2), 193-208.

Cordato, R. E. (1989, Spring). Subjective Value, Time Passage, and the Economics of Harmful Effects. Hamline Law Review, 12(2), 229-244.

Cordato, R. E. (1992A, Fall). Knowledge Problems and the Problem of Social Cost. Journal of the History of Economic Thought, 14, 209-224.

Cordato, R. E. (1992B). Welfare Economics and Externalities in an Open-Ended Universe: A Modern Austrian Perspective. Boston: Kluwer.

Cordato, R. E. (1997, Winter). Market-Based Environmentalism and the Free Market: They're Not the Same. The Independent Review, 1(3), 371-386.

Costea, D. “. (2003, Fall). A Critique of Mises's Theory of Monopoly Prices. The Quarterly Journal of Austrian Economics, 6(3), 47 - 62. Retrieved from http://www.mises.org/journals/qjae/pdf/qjae6_3_3.pdf

DiLorenzo, T. J. (1996). The Myth of Natural Monopoly. Review of Austrian Economics, 9(2), 43-58. Retrieved from http://www.mises.org/journals/rae/pdf/rae9_2_3.pdf

DiLorenzo, T., \& High., J. (1988, 07). Antitrust and Competition, Historically Considered. Economic Inquiry, 26(1), 423-435.

Doherty, B. (2012). The Increasingly Libertarian Milton Friedman. Retrieved from Reason: http://reason.com/archives/2012/11/20/the-increasingly-libertarian-milton-frie/print

Donahue, P. (2007, 07 14). Milton Friedman - Greed. Retrieved 12 2012, from Youtube: http://www.youtube.com/watch?v=RWsx1X8PV_A

Ebenstein, L. (2012). The Indispensable Milton Friedman. Washington, DC: Regnery Books.

Encyclopedia. (2012). What percentage of animals are invertebrates? Retrieved from Answers Encyclopedia: http://answers.encyclopedia.com/question/percentage-animals-invertebrates90468.html

FF. (n.d.). Mission \& History. Retrieved from The Friedman Foundation for education choice: http://www.edchoice.org/About-Us/Mission---History.aspx

Flynn, J. R. (1984). The mean IQ of Americans: Massive gains 1932 to 1978. Psychological Bulletin, 95(1), 29-51.

Flynn, J. R. (1987). Massive IQ gains in 14 nations: What IQ tests really measure. Psychological Bulletin, 101(2), 171-191.

Flynn, J. R. (2007). What is Intelligence?: Beyond the Flynn Effect. Cambridge: Cambridge University Press.

Flynn, J. R. (2012 ). Are We Getting Smarter?: Rising IQ in the 21st Century. Cambridge: Cambridge University Press.

Fox, G. (2007, Fall). The Real Coase Theorems. The Cato Journal: An Interdisciplinary Journal of Public Policy Analysis, 27(3), 373-396. Retrieved from http://www.cato.org/pubs/journal/cj27n3/cj27n3-5.pdf 
Block W. Was Milton Friedman a socialist? Yes.

MEST Journal Vol.1 No.1 pp. 11 - 26

Friedman, M. (1962). Capitalism and Freedom. Chicago: University of Chicago Press.

Friedman, M. (1962). Capitalism and Freedom. Chicago: University of Chicago Press.

Friedman, M. (1999, March/April). Policy Forum: The Business Community's Suicidal Impulse. Cato Policy Report, 21(2), 1-16. Retrieved from http://www.cato.org/pubs/policy_report/v21n2/friedman.html

Friedman, M. (2003, 03 04). Milton Friedman on Vouchers. (C. Michelle, Interviewer) CNBC. Retrieved from http://www.edchoice.org/The-Friedmans/The-Friedmans-on-School-Choice/MiltonFriedman-on-Vouchers.aspx

Friedman, M. (2012A). End the fed. Retrieved from The Money Masters: http://www.themoneymasters.com/the-money-masters/milton-friedman-end-the-fed/\#header

Friedman, M. (2012B, 05 9). Milton Friedman PBS free to chose $1980 \mathrm{Vol} 1$ of 10 Power of the Market. Retrieved from YouTube: http://www.youtube.com/watch?v=f1Fj5tzuYBE

Friedman, M., \& Boorstin, D. (1951). How to plan and pay for the safe and adequate highways we need.

Friedman, M., \& Friedman, R. (1998). Two Lucky People: Memoirs. Chicago: University of Chicago Press.

Friedman, M., \& Friedman, R. D. (1980). Free to chose. New York: Harcourt Brace Jovanovich.

Gillespie, N. $(2005,05)$. The father of modern school reform. Retrieved from reason.com: http://reason.com/archives/2005/12/01/the-father-of-modern-school-re

Gordon, D. (1998). Secession, State, and Liberty. New Brunswick, N.J.: Transaction.

High, J. (1984-1985). Bork's Paradox: Static vs Dynamic Efficiency in Antitrust Analysis. Contemporary Policy Issues, 3, 21-34.

Hoppe, H.-H. (2004, 10 11). The Ethics and Economics of Private Property. Retrieved from LewRockwel.com: http://www.lewrockwell.com/hoppe/hoppe11.html

Hoppe, H.-H. (2006). The Economics and Ethics of Private Property: Studies in Political Economy and Philosophy. Second Edition. Auburn, AL: Ludwig von Mises Institute. Retrieved from http://mises.org/books/economicsethics.pdf

Hülsmann, J. G. (2003). Secession and the Production of Defense. In H.-H. Hoppe, The Myth of National Defense: Essays on the Theory and History of Security Production (pp. 369-414). Auburn, AL: The Ludwig von Mises Institute. Retrieved from http://mises.org/etexts/defensemyth.pdf

Huntsman, J. (2011, 10 28). Romney's a 'perfectly lubricated weather vane'. Retrieved from CNN Politics: http://politicalticker.blogs.cnn.com/2011/10/28/huntsman-romneys-a-perfectlylubricated-weathervane/

Kaza, G. (1997, 06). The Mont Pelerin Society's 50th Anniversary. The Freeman, 347-351. Retrieved from http://www.fee.org/the_freeman/detail/the-mont-pelerin-societys-50th-anniversary

Kinsella, S. (2009, 08 07). Was Mises an Anarchist? Retrieved from StephanKinsella.com: http://www.stephankinsella.com/2009/08/was-mises-an-anarchist/

Krauss, M. (1999, Spring). Tort Law, Moral Accountability, and Efficiency: Reflections on the Current Crisis. Markets and Morality, 2(1). Retrieved from http://www.acton.org/publicat/m_and_m/1999_spr/krauss.html

Krecke, E. (1996, 03). "Law and the Market Order: An Austrian Critique of the Economic Analysis of Law. Journal des Economistes et des Etudes Humaines, 7(1), $19-37$.

Kreptul, A. (2003, Fall). The Constitutional Right of Secession in Political Theory and History. The Journal of Libertarian Studies, 17(4), 30-100. Retrieved from http://www.mises.org/journals/jls/17_4/17_4_3.pdf 
Block W. Was Milton Friedman a socialist? Yes.

MEST Journal Vol.1 No.1 pp. 11 - 26

Lewin, P. ( 1982, Spring). Pollution Externalities: Social Cost and Strict Liability. Cato Journal, 2(1), 205-229.

Lind, M. ( 2012 , 08 07). Thank you, Milton Friedman: How conservatives' economic hero helped make the case for big government. Salon. Retrieved from http://www.salon.com/2012/08/07/thank_you_milton_friedman/

Lindsey, R. (2006, 05). Do Economists Reach A Conclusion on Road Pricing? The Intellectual History of an Idea. Econ Journal Watch, 3(2), 292-379.

Malcolm, N. (2001). Ludwig Wittgenstein: A Memoir. Oxford: Oxford University Press.

Marx, K. ( 1875). Critique of the Gotha Program. Retrieved from Marxists Internet Archive: http://www.marxists.org/archive/marx/works/1875/gotha/ch01.htm

McChesney, F. (1991). Antitrust and Regulation: Chicago's Contradictory Views. Cato Journal, 10.

McGee, R. W. (1994A, Fall). Secession Reconsidered. The Journal of Libertarian Studies, 11(1), 1133. Retrieved from http://www.mises.org/journals/jls/11_1/11_1_2.pdf

McGee, R. W. (1994B, Spring). Secession as a Tool for Limiting the Growth of State and Municipal Government and Making it More Responsive: A Constitutional Proposal. Western State University Law Review, 21, 499. Retrieved from http://heinonline.org/HOL/LandingPage?collection=journals\&handle=hein.journals/wsulr21\&div $=29 \& \mathrm{id}=\&$ page $=$

Memehunter. ( 2012, 10 29). The Mont Pèlerin Society: The ultimate neoliberal Trojan horse. The Daily Knell. Retrieved from http://thedailyknell.wordpress.com/2012/10/29/the-mont-pelerinsociety-the-ultimate-neoliberal-trojan-horse/

Mises, L. (1978). Liberalism (In the Classical Tradition). Kansas City: Sheed Andrews, \& McMeel, Inc.

Mises, L. v. (1969). Omnipotent Government. New Rochelle, N.Y.: Arlington House.

Mises, L. v. (1983). Nation, State and Economy. Retrieved from Ludwig von Mises Institute: http://mises.org/nsande/pt1iich2 b.asp

Mises, L. v. (2009). Socialism - an economic and sociological analysis. Auburn, Alabama: Ludwig von Mises Institute. Retrieved from http://books.google.rs/books?id=dPkB7AiURigC\&pg=PA20; $\mathrm{http}: / / \mathrm{mises}$. org/books/socialism/preface_second_german_edition.aspx

Mullat, J. E. (2012, 10 19). The Welfare Policy Dilemma of a Negative Income Tax System: Normative Approach. Retrieved from Social Science Research Network - Tomorrow's Research Today: http://papers.ssrn.com/sol3/papers.cfm?abstract_id=2165949

Murphy, R. P. (2008, 11 24). An Open Letter to Gary Becker re: Depressions. Retrieved from Ludwig von Mises Institute: http://mises.org/story/3220

North, G. (1976). Educational Vouchers: The Double Tax. The Freeman, 26(5). Retrieved from http://www.thefreemanonline.org/featured/educational-vouchers-the-double-tax

North, G. (1990). Tools of Dominion: The Case Laws of Exodus . Tyler, TX: Institute for Christian Economics.

North, G. (1992). The Coase Theorem. Tyler, TX: The Institute for Christian Economics.

North, G. (2002, Fall). Undermining Property Rights: Coase and Becker. The Journal of Libertarian Studies: An Interdisciplinary Review, 16(4), 75-100. Retrieved from http://www.mises.org/journals/jls/16_4/16_4_5.pdf

North, G. (2011, 06 30). Just Say No to School Vouchers . . Again. Retrieved from LewRockwell.com: http://lewrockwell.com/north/north999.html

Northrup, C. C. (2003). The American Economy: A Historical Encyclopedia (Vol. 2). Santa Barbara, California: ABC-CLIO, Inc. Retrieved from http://books.google.ca/books?id=3DE4P7NdaycC\&pg=PA493\&lpg=PA493\&dq=milton+friedm 
Block W. Was Milton Friedman a socialist? Yes.

MEST Journal Vol.1 No.1 pp. 11 - 26

an+eminent+domain\&source=bl\&ots=mv_HfZ_WtZ\&sig=3c13pHNaluaAf2MHQSCS3xDGbpA \&hl=en\&sa=X\&ei=3z-wUPe2BoGQiQKuvlB4\&ved=0CD4Q6AEwAw;

Pena, D. S. (2011, 04 04). You Might Be a Marxist If ... You Believe in From Each According to Their Abilities, to Each According to Their Needs. Retrieved from PA Political Affairs - Marxism. Fresh. Daily.: http://politicalaffairs.net/you-might-be-a-marxist-if-you-believe-in-from-eachaccording-to-their-abilities-to-each-according-to-their-needs/

Polya, G. (2007). 'To each according to his needs' for Spaceship Earth. State of Nature: An Online Journal of Radical Ideas. Retrieved from http://www.stateofnature.org/toEachAccording.html

RB. (2012, 02 15). For the Welfare of All. Retrieved from Hannah Arendt Center Bard College: http://www.hannaharendtcenter.org/?tag=negative-income-tax

Rockwell, J. L. (1998, 09 1). Vouchers: Enemy of Religion. Retrieved from Ludwig von Mises Institute: http://www.mises.org/fullstory.aspx?control=106\&id=79

Rockwell, L. (2000). Education and the Election. Retrieved from LewRockwell.com: http://www.lewrockwell.com/rockwell/educationandelection.html

Rockwell, L. (2002, 07 02). Vouchers: Another Name for Welfare. Retrieved from LewRockwell.com: http://www.lewrockwell.com/rockwell/voucher2.html

Rome, G., \& Block., W. (2006). Schoolhouse Socialism. Journal of Instructional Psychology, 33(1), 8388. Retrieved from http://findarticles.com/p/articles/mi_m0FCG/is_1_33/ai_n16118909/?tag=content;col1

Romney, M. (2012, 10 3). THE REAL MITT ROMNEY - THE WEATHER-VANE CANDIDATE--- $A$ collection of flip-flips and suit changes from the past, present and no doubt the future.... Retrieved from THE REAL MITT ROMNEY - THE WEATHER-VANE CANDIDATE: http://mittromney2012potus.blogspot.com/

Ron, P. (2010). End the Fed. New York, N.Y.: Grand Central Publishing.

Rothbard, M. N. (1971 [2002]). Milton Friedman Unraveled. Individualist, 3-7. Retrieved from http://www.lewrockwell.com/rothbard/rothbard43.html

Rothbard, M. N. (1973, Spring). Value Implications of Economic Theory. The American Economist, 3539. Retrieved from http://mises.org/page/1412

Rothbard, M. N. (1982, Spring). Law, Property Rights, and Air Pollution. Cato Journal, 2(1). Retrieved from http://www.mises.org/rothbard/lawproperty.pdf; http://mises.org/story/2120

Rothbard, M. N. (1994). Vouchers: What Went Wrong? In M. N. Rothbard, Making Economic Sense (pp. 1, 8). Auburn, AL: The Ludwig von Mises Institute. Retrieved from http://mises.org/econsense/ch43.asp

Rothbard, M. N. (1995). Making Economic Sense. Auburn, AL: Mises Institute.

Rothbard, M. N. (1997, Spring). Value Implications of Economic Theory," Logic of Action I (Cheltenham, UK: Edward Elgar), pp. American Economist, 35-39.

Rothbard, M. N. (2002, Fall). Milton Friedman Unraveled. Journal of Libertarian Studies, 16(4), 37-54. Retrieved from http://www.mises.org/journals/jls/16_4/16_4_3.pdf

Rothbard, M. N. (2004 [1962]). Man, Economy and State. Auburn AL: Ludwig von Mises Institute, Scholar's Edition. Retrieved from http://www.mises.org/rothbard/mes.asp

Saletan, W. (2012, 08 23). The Abortion Weathervane. Retrieved from Slate: http://www.slate.com/articles/news_and_politics/frame_game/2012/08/romney_abortion_and_ rape_he_s_a_flip_flopper_not_an_extremist_html

Salisbury, D. F. (2003, 08 28). What Does a Voucher Buy? A Closer Look at the Cost of Private Schools. Cato Institute Policy Analysis, 486. 
Block W. Was Milton Friedman a socialist? Yes.

MEST Journal Vol.1 No.1 pp. 11 - 26

Seagraves, J. (2008, 08 26). "Privatize The Roads!" Says PhD Economist. Retrieved from Cutizen Economists: http://www.citizeneconomists.com/blogs/2008/08/26/privatize-the-roads-saysphd-economist/comment-page-1/\#comment-950768

Shugart II, W. F. (1987). Don't Revise the Clayton Act, Scrap It! Cato Journal(6), 925.

Smith, J. F. (1983, Jan-Feb). Why not Abolish Antitrust? Regulation, 23.

Smithson, J. (2010, 02 25). Secession as a way of achieving anarchy. Retrieved from freedomain: http://board.freedomainradio.com/forums/p/24619/190802.aspx

Stringham, E. (2001, Summer). Kaldor-Hicks Efficiency and the Problem of Central Planning. Quarterly Journal of Austrian Economics, 4(2), 41-50. Retrieved from http://www.mises.org/journals/qjae/pdf/qjae4_2_3.pdf

Stringham, E. P., \& White, M. (2004). Economic Analysis of Tort Law: Austrian and Kantian Perspectives. (M. Oppenheimer, \& N. Mercuro., Eds.) Law and Economics: Alternative Economic Approaches to Legal and Regulatory Issues, 374-392. Retrieved from http://www.sjsu.edu/stringham/docs/Stringham.and.White2005.pdf

Summers, L. (2006, 11 19). The Great Liberator. The New York Times. Retrieved from http://www.nytimes.com/2006/11/19/opinion/19summers.html

Terrell, T. D. (1999, Fall). Property Rights and Externality: The Ethics of the Austrian School. Journal of Markets and Morality, 2(2). Retrieved from http://www.questia.com/read/1G1186433151/property-rights-and-externality-the-ethics-of-the

TiMT. (2012, 08 13). Mitt "The Lubricated Weathervane Candidate" Romney's 18 Flip Flop Positions with Videos. Who is Mitt Romney and Can You Really Trust Him to be Your President? Retrieved from The People's View: http://www.thepeoplesview.net/2012/08/mitt-lubricatedweathervane-candidate.html

Tucker, J. (1998A, 03). Controversy: Are Antitrust Laws Immoral? Journal of Markets \& Morality, 1(1), 75-82. Retrieved from http://www.acton.org/publications/mandm/mandm_controversy_35.php

Tucker, J. (1998B, 03). Controversy: Are Antitrust Laws Immoral? A Response to Kenneth G. Elzinga. Journal of Markets \& Morality, 1(1), 90-94. Retrieved from http://www.acton.org/publications/mandm/mandm_controversy_37.php

Vance, L. M. (1996, 11). Friedman's Mistake. The Free Market, 14(11).

Wiki. (2012, 12 02). Ludwig von Mises. Retrieved from Wikipedia: http://en.wikipedia.org/wiki/Ludwig_von_Mises\#Criticisms

Wright, G. (2010, 0124$)$. The secession approach to convert people to anarchy. Retrieved from Ludwig von Mises Institute: https://mises.org/community/forums/t/13748.aspx

Yates, S. (2002A, 07 06). "Vouchers and Government Control. Retrieved from LewRockwell.com: http://www.lewrockwell.com/yates/yates58.html

Yates, S. (2002B, 07 13). Refuting the voucherites. Retrieved from http://www.lewrockwell.com/yates/yates59.html

Young, A., \& Block., W. ( 1999). Enterprising Education: Doing Away with the Public School System. International Journal of Value Based Management, 12(3), 195-207. Retrieved from http://www.mises.org/etexts/enterprisingedu.pdf; http://www.mises.org/story/2216; http://www.walterblock.com/publications/enterprising_education.pdf

Received for publication: $\quad$ 10.12.2012

Accepted for publication: $\quad$ 28.12.2012 
Block W. Was Milton Friedman a socialist? Yes.

MEST Journal Vol.1 No.1 pp. 11 - 26

\section{How to cite this article?}

Style - APA Sixth Edition:

Block, W. E. (2013, 01 15). Was Milton Friedman A Socialist? Yes. (Z. Čekerevac, Ed.) MEST Journal, 1(1), 11-26. Retrieved from www.meste.org/mest/MEST_1_2013/_02.pdf.

doi: 10.12709/mest.01.01.01.02.pdf

Style - Chicago Fifteenth Edition:

Block, Walter E. "Was Milton Friedman A Socialist? Yes." Edited by Zoran Čekerevac. MEST Journal (MESTE NGO) 1, no. 1 (01 2013): 11-26.

Style - GOST Name Sort:

Block Walter E. Was Milton Friedman Socialist? Yes. [Journal] = Was Milton Friedman socialist? Yes // MEST Journal / ed. Čekerevac Zoran. - Belgrade - Toronto : MESTE NGO, 01 15, 2013. - 1 : Vol. 1. - pp. 11-26.

Style - Harvard Anglia:

Block, W. E., 2013. Was Milton Friedman Socialist? Yes.. MEST Journal, 15 01, 1(1), pp. 11-26.

Style - ISO 690 Numerical Reference:

Was Milton Friedman Socialist? Yes. Block, Walter E. [ed.] Zoran Čekerevac. 1, Belgrade - Toronto : MESTE NGO, 01 15, 2013, MEST Journal, Vol. 1, pp. 11-26. 